Agricultural turns, geographical turns: retrospect and prospect

Carol Morris and Nick Evans

Correspondence to:

Carol Morris, Countryside and Community Research Unit, University of Gloucestershire, Francis Close Hall, Swindon Road, Cheltenham, Gloucestershire, GL50 4AZ. Tel: 01242 543281. Email: cmorris@chelt.ac.uk

Paper resubmitted to the Journal of Rural Studies, November 2002 


\title{
Agricultural turns, geographical turns: retrospect and prospect
}

\begin{abstract}
It is accepted that British rural geography has actively engaged with the 'cultural turn', leading to resurgence in research within the sub-discipline. However, a reading of recent reviews suggests that the cultural turn has largely, if not completely, bypassed those geographers interested in the agricultural sector. It is conceded that farming centred engagements with notions of culture have been relatively limited compared with those concerned with the non-agricultural aspects of rural space. Indeed, agricultural geography represents something of an awkward case in the context of the disciplinary turn to culture, a situation that demands further exposition. However, in seeking explanation, it becomes evident that research on the farm sector is more culturally informed than initially appears. This paper argues that there have been both interesting and important engagements between agricultural geography and cultural perspectives over the past decade. The paper elaborates four specific areas of research which provide evidence for concern about the 'culture' within agriculture. The future contribution that culturally informed perspectives in geographical research can bring to agricultural issues is outlined by way of conclusion.
\end{abstract}

\section{A turn to culture in rural geography}

It is widely accepted that human geography in the UK has experienced a 'cultural turn'. The 'moment' of this turn has been dated to the late 1980s / early 1990s, enabling it be located within "the wider set of debates that emerged in the late 1980s around postmodernism which in large part were the vehicles for geography's entry into new fields of cultural theory" (Barnett, 1998a, p.381). Dissatisfaction with the 
theoretical hegemony of political economy is also identified as a cause of the turn to culture at this time. As a consequence, geographical inquiry has become more sensitive to the role of culture as a process in the mediation of all aspects of life. In this way, culture has been recognised as something that is central to the organisation and operation of society, not some universal or residual category that is marginal to social, political and economic concerns. Consensus about the existence of a cultural turn is, nonetheless, accompanied by ongoing debate over its scope and also its effects, both positive and negative, on the substance of geographical enquiry (Harvey, 2000; Philo, 2000). Recent commentaries on the cultural turn appear to agree that it has many manifestations yet is neither coherent nor unified (see for example, McDowell, 1994; Crang, 1997; Barnett, 1998a; Philo, 2000). Similarly, the precise meanings of 'culture' and 'the cultural' are strongly contested. However, Barnett (1998a, p.380) argues that a common thread connecting the 'myriad projects' constitutive of the cultural turn is:

"a commitment to epistemologies, often loosely labelled 'post-structural' that emphasise the contingency of knowledge claims and recognise the close relationship among language, power and knowledge. Both epistemologically and in the construction of new empirical research objects, the cultural turn is best characterised by a heightened reflexivity toward the role of language, meaning and representations in the constitution of reality and knowledge of reality".

This has not only had implications for methodology (especially an increase in interest in qualitative approaches such as ethnography and the use of techniques such as discourse analysis), but also for the types of 'data' sources, many of which would have previously been of little concern or interest to geographers. A wide variety of 
texts and images have become the subject of interpretation (for an example of the possibilities, see Burgess' (1990) discussion of media texts analysed utilising Johnson's (1986) 'circuit of culture'). This shift of focus has attracted its critics, contending that the cultural turn has led human geographers to disengage with the study of 'the material' and 'gritty social reality' in favour of identities and representation (Philo, 2000).

A key observation from such exchanges is that although a 'cultural turn' had become firmly embedded generally within British human geographical thinking and practice by the mid 1990s, its influence has been differential across geographical subdisciplines. For example, social geography particularly has been refashioned with debates raging over the extent to which cultural geography has marginalized this subdiscipline (Valentine, 2001). In turn, there have been important repercussions for the distinctive subject area of 'rural geography' in the UK which draws upon insights from across the systematic branches of geographical inquiry (and indeed has been influential in blurring the boundaries of knowledge between them). Cloke (1997) and Little (1999), amongst others, have argued that British rural geography has actively engaged with the cultural turn, with reinvigorating consequences. An explanation is the strength of the relationship of rural geography as a subject area with the social geography systematic. However, less confidence can be placed in this assertion when the sub-field of agricultural geography is brought into the equation. It is the purpose of this paper to consider explicitly the past, present and future relationship between research in agriculture and the geographical turn to culture.

\section{The awkward case of agricultural geography}


Agricultural geography represents something of an 'awkward' case when attempting to review the influence of the cultural turn in this context. A root cause is the inability of institutionally-defined divisions of geography to deal adequately with a subject matter that is so enmeshed in political, economic, social and environmental factors. This is borne out by the alliances that agricultural geography has with other disciplines that have a distinct status such as agricultural economics, rural sociology, political science and anthropology. In attempting to define its position, for many years agricultural geography was a significant sub-set of economic geography, but the decline of farming fortunes in the 1980s led to concerns about the erosion of its significance within this systematic branch of the discipline (Marsden et al., 1996). This was a time when rural geography was undergoing rapid development in which social issues were prominent $^{1}$. Indeed, as a non-farm rural social geography flourished ${ }^{2}$, agricultural geography floundered in 'diminishing returns' (Bowler and Ilbery, 1987). The marginalisation of agricultural geography was such that fundamental questions were raised about its value and continued existence (Marsden, 1988; Atkins, 1988). One outcome has been to relegate agricultural geography to something of a twilight position between rural and economic geography. The former has emerged as the most common source of alignment for researchers and it is this position that helps inform the perspective adopted in this paper.

A wide range of agrarian issues continues to be researched apace, even though a direct association with agricultural geography is rarely asserted (Morris and Evans, 1999). The 'grafted' nature of the relationship between a previously economically founded

\footnotetext{
${ }^{1}$ As early as the mid-1970s, the Agricultural Geography Study Group of the Institute of British Geographers had become transmogrified into the Rural Geography Study Group, reflecting the broadening interests of researchers which could not comfortably be contained within systematic branches of the discipline.
} 
agricultural geography and rural geography is sometimes visible as researchers maintain a distinct farm or non-farm focus to their work rather than cutting across all aspects of rural politics, society and economy. For example, a recent textbook on rural change (Ilbery, 1998) begins with two excellent review chapters covering economic and social perspectives (Marsden, 1998; Phillips, 1998), yet they are notable for the way in which agriculture appears frequently in the first and then hardly at all in the second.

Upon reflection, a defining factor in the difference between the treatment of agricultural and non-agricultural material within the confines of British rural geography is the cultural turn. The application of insights from structural political economy served to enrich theoretically both the agricultural and social strands of rural geography from the late 1980s, but it can be purported that the cultural turn has not. It is with an exposition of this assertion that the paper is concerned. To do this, the paper is structured into three subsequent sections. First, reasons for differences in cultural application within agricultural and non-agricultural rural geography research, already hinted at in the paper, are explored in more detail. Second, whether an argument dismissing a cultural turn in agricultural geography is in fact tenable is explored. Third, the potential future contributions to be made by culturally informed perspectives in agricultural research are discussed. The scope of this paper is principally limited to British scholarship where the cultural turn in human geography has been strongest (Philo, 2000; Valentine, 2001). British rural geographers have been at the forefront of responding to the opportunities and challenges of the cultural turn, but the ramifications for agricultural geography in the UK remain hazy. Only through

\footnotetext{
${ }^{2}$ As witnessed by the profusion of new rural geography texts (Phillips and Williams, 1984; Gilg, 1985; Pacione, 1985)
} 
critical review can some basic questions be answered about agricultural geography which have until now been largely avoided. These concern its health, usefulness and future relevance to the advancement of geographical thinking, a process in which the wide canvas presented by agricultural issues offers potentially unrivalled opportunities for conceptual and methodological application. For the purposes of initial illustration, examples are drawn largely, but not exclusively, from work that focuses attention on 'the farm', as opposed to other locations within the agri-food system. We are aware that this has resonance with the outmoded pre-structuralist agricultural geography that has been left behind, one where

"traditional preoccupations usually mean keeping one foot firmly placed, if not in the farmyard, then within an institutional arena that treats agriculture as a special case, an outlook that undermines the contribution of agricultural geography to the discipline as a whole" (Marsden et al. 1996, p.361).

It is fully appreciated that agricultural research inevitably spills into broader domains than those indicated above, yet agriculture remains a valid starting point from which exciting forms of geographical investigation can radiate out (Morris and Evans, 1999).

\section{Agri-, but not cultural?}

Almost by definition, the term 'agriculture' could conceivably be expected to encompass research with a significant cultural element. Indeed, as Eagleton (2000, p.1) highlights, "one of the original meanings [of culture] is 'husbandry', or the tending of natural growth... The word 'coulter' which is a cognate of 'culture', means the blade of a ploughshare. We derive our word for the finest of human activities from 
labour and agriculture". However, Cloke (1997) and Little's (1999) commentaries of the cultural turn in rural studies are remarkable for their silence about the relative significance of the cultural turn within agricultural geography research. As outlined in the introduction, rural studies has enthusiastically embraced the cultural turn (Little, 1999). It is this engagement, between the rural and the cultural, so Cloke (1997) suggests in an editorial of the Journal of Rural Studies, that accounts for a resurgence in British rural research. He proceeds to outline three main foci for cultural studies which possess a specific rural context for research namely, landscape (mainly, its role in national identity), 'hidden' others and the spatiality of nature. In a subsequent review, Little (1999) takes up the baton to identify and critique the following areas of culturally informed work within rural studies: marginality and the rural 'other'; representations of rurality (emphasising the importance of the notion of the rural idyll); and nature-society relations. Both of these reviews suggest that the cultural turn has, at best, skirted the fringes of interest of agricultural geographers. Neither makes explicit reference to the cultural turn in the context of agricultural research. For example, Little (1999) refers, within work on nature-culture relations, to the work of Woods (1998) on 'mad cows and hounded deer'. The starting point here is the way that animals are sidelined in political debates yet are central to constructions of rurality, effectively exposed by the paper, rather than the place of such animals within agricultural systems. Meanwhile, Cloke (1997, p.369) describes how "culturally inspired studies are being overlain on very important existing topographies of...behavioural and political-economic geographies of agriculture". However, he does not go on to elaborate the type and scope of work this process of overlaying has produced, if indeed this is implied. It is unclear whether he is suggesting that geographies of agriculture are only behavioural and political economic, never 
'cultural'. Alternatively, this view can be interpreted as echoing the sentiments of Philo (1992) in which culture is an 'additional ingredient' for rural geography rather than the more fundamental basis for reflexivity in thinking about rural studies advocated by Murdoch and Pratt (1993). This lack of specificity appears all the more surprising given that the three areas of 'culturally informed' rural studies that Cloke identifies have all been of interest (albeit sporadically) to those working within agricultural research, as illustrated later in the paper. The paradoxical situation portrayed here in which rural geography has been a vanguard of the cultural turn whilst agricultural geography remains a cultural 'country backwater' demands explanation. Five main reasons for this situation can be postulated.

The first reason that can be advanced relates to 'research fashion'. Early in the 1990s, when the cultural turn was beginning to impact upon rural studies, research increasingly became concerned with those aspects of the rural beyond the agricultural. Larger numbers of new researchers entering rural geography have appeared to favour the study of non-farming rural matters rather than to engage with agriculture ${ }^{3}$. This represents a reversing of, if not a deliberate reaction to, the situation in rural geography's 'fallow years', when the rural was conflated with the agricultural (Cloke, 1997). Therefore, a limited influence on agriculture from the cultural turn may, in part, be a simple product of numbers of researchers, at least within rural geography, working on agricultural and agri-food topics compared with those investigating the non-agricultural aspects of rural society.

\footnotetext{
${ }^{3}$ Evidenced by the relative balance of rural and agricultural papers presented at events hosted by the Rural Geography Research Group of the RGS-IBG and the Rural Economy and Society Study Group.
} 
Second, and more fundamentally, the countryside has become transformed in recent times as a place of consumption (Marsden et al., 1993; Murdoch and Marsden, 1994), the profusion of its representation through television, radio, texts and products lending itself particularly to cultural analysis (Cloke, 1997). Hence, 'rural' research has been quicker to engage with notions of consumption than 'agricultural' research with its long history of concern with production. If, as some have claimed, the 'consumption turn' in social science is a parallel development (perhaps even synonymous) with the cultural turn ${ }^{4}$, it is easy to see how those areas of research which have traditionally focused on matters of production, such as agriculture, have been less subject to the influence of the cultural turn than those areas of rural research that are broadly concerned with consumption. As Whatmore (2000, p.12) points out:

“Until very recently, the last 'link in the chain' of the agro-food system ... [food consumption] ... has been paid remarkably little attention by agricultural geographers ... It has tended to be treated by default as an unproblematic and socially undifferentiated process - after all everyone has to eat."

Thus, agricultural geographers have remained production focused precisely at a time when the application of scientific knowledge over many years has tended to standardise production methods whilst the consumption of food products has become highly differentiated (fast food, cook-chill meals, meat substitutes and so on - see Section 4.4).

Third, the hegemony of particular theoretical perspectives can be highlighted. Just when the cultural turn was beginning to interest rural researchers, a number of key

\footnotetext{
${ }^{4}$ The strong co-existence, or correlation between consumption and the cultural has been observed by Jackson and Thrift (1995), in their review of geographies of consumption: "There is still a tendency for studies of consumption to be exclusively 'cultural',
} 
commentators working in, and arguably dominating, research in agricultural geography were deploying, with considerable persuasiveness, modified political economy perspectives (Marsden et al., 1986; Bowler and Ilbery, 1987; Marsden, 1988; see Marsden et al., 1996 for overview). As Morris and Evans, (1999) have argued, political economic narratives have effectively overshadowed all other types of analysis in agricultural geography. As its main proponents have been at pains to point out (Whatmore et al., 1996), the original purpose of modifying agrarian political economy (a point often overlooked) was to facilitate engagement with diversity, including culturally inspired explanations for uneven development in agriculture. In practice, the power and complexity of the political economy approach, at least in the late 1980s and early years of the 1990s, may have been such to preoccupy researchers who largely, up to that point, had been grounded in searching for explanations of changing land use patterns from within farming itself. Ironically, attention became diverted away from the potential insights offered by culturally sensitive analyses. This is suggestive of the outcome observed by Hughes et al. (2000, pp. 10-11) who argue that this "may be partly explained by the interests of key 'gate keepers' within these research areas", although they acknowledge that this is an issue which requires further unpacking.

The fourth explanation for a relatively limited agri-cultural turn lies in the policy orientation of a significant proportion of the research that can be considered to represent agricultural geography. As Morris and Evans (1999, p.354) have argued,

"it is understandable that [agricultural] work has not been more culturally sensitive, because much of it has been delivered within a 'policy evaluation' 
mould. The monitoring brief demanded by government agencies leads inevitably to questionnaire-type approaches...",

rather than more in-depth methodologies required by cultural perspectives (Young et al., 1995). These sentiments are echoed by Cloke (1997) and Milbourne (2000), who both suggest that there is an incompatibility between qualitative rural research (characteristic of the cultural turn) and contemporary policy discourses which valorise numerical data.

For a fifth explanation, we must return to the traditional positioning of agricultural geography within human geography as a branch of economic geography. This had an overbearing influence on the orientation of agricultural research, one that political economy theorisations endorsed rather than removed ${ }^{5}$. One clear example of this is the treatment of farm animals (Yarwood and Evans, 2000), which have persistently been conceptualised as

"homogenous items of mass production, broad types within policy mechanisms or at best 'quality products' within the food production system" (Morris and Evans, 1999 p.355).

A consequence of this is that

"little has been written on the association of animals with local folklore and culture, so that a discourse is lacking on the importance of particular animals to particular locales, and to the construction of these locales" (Morris and Evans, 1999, p.355).

\footnotetext{
Thrift, 1995, p.228).

${ }^{5}$ It is against this critique that agricultural geography slipped further into an indefinable position straddling economic geography and a vibrant encultured rural geography. Also significant was the loss of an annual review of agricultural geography as a 'discrete subject' from the journal Progress in Human Geography in 1993 to be subsumed by that of rural geography (respectively, Whatmore, 1993; Marsden, 1994).
} 
With economic geography only very recently 'encultured' (Thrift and Olds, 1996; Crang. 1997), a seal of legitimacy to a culturally sensitive approach within agricultural geography has at last been achieved from its root within the discipline.

\section{An agri-cultural turn?}

To dismiss the meaning of culture and a cultural turn to agricultural geographers on the basis of the evidence just presented would be overly superficial. Contrary to what is implied by commentaries on rural geography, there is clear evidence of a cultural turn within agricultural research. This paper asserts that there have been both interesting and important engagements between agricultural geographers and cultural perspectives over the past decade. Buttel (2001) has made a similar observation in the context of his rural sociological account of late twentieth century (principally North American) agrarian political economy. Indeed, he goes as far as to say that a cultural turn within the sociology of agriculture represents a "contender for intellectual dominance" with agrarian political economy, with the former developed as a result of ambivalence, or in some cases direct opposition, to the latter (Buttel, 2001, p.172). The paper now concerns itself with an overview and commentary on a body of literature that provides illustrative evidence for an 'agri-cultural turn' within geography.

In the sub-sections that follow, some of the key points of articulation between agricultural research and 'the cultural' are identified. These key points emerge from new critical masses of research, one characteristic element within which is the adoption of the 'heightened reflexivity' to the construction of knowledge identified by 
Barnett (1998a). However, it must be noted that the work considered typically neither has the specific aim of defining the meaning of culture within agriculture nor locating itself as part of any turn to culture. Before doing so, it is important to acknowledge that this work cannot be solely attributed to the particular set of intellectual debates that have been circulating within human geography over the past decade. The "valuable manoeuvres" of humanistic, and more particularly, behavioural studies of agriculture in the 1970s and 80s must also be recognised as "paving the way for the cultural turn of more recent vintage" (Philo, 2000, p.32). These precursors to any notion of an agri-cultural turn entailed "detailed investigations into the shadowy recesses of human perception, cognition, interpretation, emotion, meanings and values, creating a rich vein of inquiry" (Philo, op cit). The considerable body of behavioural investigations of agriculture, most notably studies of farmers' goals, values and attitudes, should be highlighted in this context (for example, Gasson, 1973; Newby et al., 1977; Ilbery, 1985; Gillmor, 1986). Commentary on agri-cultural research of the 1990s must also acknowledge the significant contribution of social anthropological studies of rural communities undertaken in the 1950s and 1960s (such as those by Arensberg and Kimball, 1940; Rees, 1950; Frankenburg, 1957; Williams, 1956 and 1963; Littlejohn 1963; Emmett, 1964) and also more recently in the 1980s and 1990s (Strathern 1982a and b; Bouquet, 1985; Middleton, 1986; Rapport 1993; Bell, 1994). Discussion of agricultural members of the communities studied is a conspicuous and recurrent feature, and oftentimes the foci. Moreover, for these authors, culture was always a principal concern of research, not something awaiting 'discovery' as reference to the (agri-)cultural turn of recent years might tend to imply. 
Four interrelated areas of work are identified and interpreted as constituting an agricultural turn in British agricultural geography: 'representations of agriculture'; 'nature-society relations'; 'heterogeneous agri-cultures'; and 'enculturing the agrifood economy'. The first two appear to have attracted much more attention than the latter two, which can be seen to represent 'emergent' areas of activity, influencing the balance of the following review. These groupings are proposed as a means of organising and commenting on the work undertaken, but it is acknowledged that any such categorisation is inevitably subjective, the product of a particular 'reading' of research interpreted as 'agri-cultural'. Furthermore, the work referred to under each heading could be (and in some cases is) positioned under more than one heading. The review does not claim to be exhaustive, nor does it set out to give the impression of acting as a

“kind of satellite circling...[agricultural]... geography’s cultural turn, claiming the 'scopic power' to see clearly all that is taking place but which others closer by cannot themselves comprehend" (Philo, 2000, p.27).

\subsection{Representations of agriculture}

One clear sign of a cultural turn within agricultural geography is research concerned with the representation of aspects of agricultural life. As Fish and Phillips (1997, p.1) have observed within the context of rural studies as a whole:

"increasing attention has been paid to images and representations of the countryside and how they are created, circulated and consumed, and also how they may influence material actions...There has also been....a concern with examining how these representations are embedded in relations of power".

Their observation can be applied to the agricultural sphere, in which both written and pictorial texts have been analysed for the meanings they encapsulate, with media texts 
being a notably popular source. Agriculture as representation has been explored through two major conduits: gender and discourse.

First, gender issues in agriculture have been a particular focus of attention, supporting Barnett's (1998a) assertion that the study of the construction of social relations of gender is one exemplar of human geography's cultural turn. Within an agricultural context, authors have begun to explore the role of the agricultural and countryside media in the construction and reproduction of farming masculinities and femininities. For example, the neglect of women in 'farming success stories' in the North American agricultural press (Walter and Wilson 1996) inspired Morris and Evans (2001) to examine the changing representations of farm women in a major UK farming publication. Portrayals of farm life were exposed as increasingly subtle in the communication of long-established patriarchal views about the roles of farm men and women. Such work is based upon academic readings of media texts, which is both interesting in itself and revealing of the ways in which powerful institutions such as the media draw upon and replicate ingrained constructions of masculinity and femininity. However, there is a danger that such analyses lead researchers away from the "patient excavation of the grain of component social lives, social worlds and social spaces" (Philo, 2000, p.37) ${ }^{6}$. One way to address such concerns is to move beyond analyses of media representations and study the various ways in which the consumers of these media products interpret, accept and resist them (for an Australian example within agriculture, see Liepins, 1996; see also Jackson and Thrift, 1995; Jackson et al., 1999). Another approach is to examine the 'process of cultural production' where

\footnotetext{
${ }^{6}$ This is not to deny those analyses e.g. by feminist scholars, that have continued to undertake 'on the ground' research with farming men and women, and which complement the text based accounts discussed here.
} 
the media 'take up and re-write more general cultural texts' (Phillips et al., 2001, p.10). As these authors have demonstrated in wider rural contexts, much scope exists for research into the production of representations of agriculture. For example, it could offer important insights into the way these processes seek to encode agriculture as an activity that is worthwhile to society, but one that can only be conducted by those with specials sets of accumulated knowledge (farmers) in a trade-off between personal fulfilment and sacrifice, sometimes even hardship, whilst displaying sensitivity to wider societal wishes such as the respect of nature, especially animals.

Nevertheless, much remains to be studied in the relationship between agriculture and the media that conceptualisation through gender has come closest to exposing. For example, agricultural geographers have been remarkably silent about the way that television and radio represent farming. Those programmes devoted solely to agriculture have become less common, as illustrated by the loss of BBC's Sunday lunchtime farming programme to the more socially and environmentally-based CountryFile in the early 1980s, or the change in title of a popular UK soap operas from 'Emmerdale Farm' to just 'Emmerdale'. They have also, with the exception of BBC Radio 4's 'The Archers', become marginalized in broadcasting schedules. Even so, agriculture remains of media interest, no doubt partly due to the ease with which the sector can be represented as in 'crisis', and a component, if not focus, for a significant number of programmes. With so much work to be done, it would be remiss not to suggest some tentative subjects in the media's 'production of production'. A cursory analysis of dramas that incorporate farming reveals at least three themes which appear to preoccupy programme-makers: farming as rusticity ('The Darling 
Buds of May', 'All Creatures Great and $\mathrm{Small}^{7}$ ); farming as conflict, especially

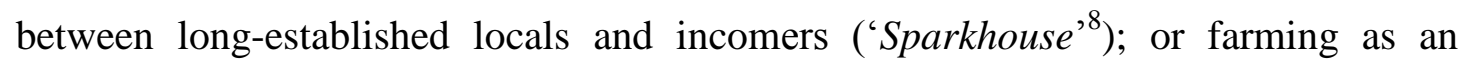
alternative lifestyle ('Down to Earth', 'Return to River Cottage'9). Rarely are the cultural values that underpin farming explored, although it must be noted that one episode of 'Living with the Enemy' broadcast on BBC2 in 1998 is a significant exception. The foundations of diametrically opposed views about the nature of farming were exposed when John, an animal rights activist, was sent to live on a traditional livestock farm for a week. In all these examples, one effect of the media in representing agriculture is the splicing together in complex ways of elements of the pastoral and anti-pastoral (see Short, 1991) which in turn exposes the limitations of this dualism.

A second area of work on the representation of agriculture is a growing body of research that has focused upon 'discourse'. "Discourse has become one of the most widely and often confusingly used terms in recent theories in the arts and social sciences, without a clearly definable single unifying concept” (Meinhof, 1993, p.161). It is certainly evident within agricultural research that there is some variation in the interpretation and use of the term. Nonetheless, there is a measure of concurrence among discourse-centred accounts of agriculture, with discourse typically taken to mean a framework, embracing "particular combinations of narratives, concepts,

\footnotetext{
7 The Darling Buds of May was an idealised representation of farm family life set in the county of Kent in the 1950s, emphasising the wholesomeness of family values and the superiority of a simple way of life over complex ways of modern living. All Creatures Great and Small was based on the comic adventures of vet 'James Herriot' which derived from a collision of a new veterinary scientific knowledge with the experiential local knowledge of livestock farmers in the Yorkshire Dales from 1936 to the early $1950 \mathrm{~s}$.

${ }^{8}$ Sparkhouse was a drama publicised as bringing up-to-date Emily Bronte's literary classic Wuthering Heights. The plot of the adaptation centred around the tension between two neighbouring families; one with a long local tradition in hill farming but experiencing severe financial difficulty and the other a wealthy family of 'incomers'.

${ }^{9}$ Down to Earth is described as a 'heart-warming' drama which follows the relocation of a London family to the rural southwest of England where a country life dream is realised. Return to River Cottage documents the 'downshifting' of London journalist Hugh Fearnley Whittingstall to a smallholding in south west England where his aim is to become as self-sufficient in food as possible.
} 
ideologies and signifying practices" (Liepins, 1996, p.9), in which something, such as agriculture, the environment, or food quality is made meaningful. Authors have been concerned to uncover the many competing discourses that exist to give meaning to specific agricultural phenomena and to explore the ways in which discourse structures experience and action. In this last respect, the relationship between discourse and power is highlighted. As Liepins (1996, p.3) argues, "discourse as a way of structuring knowledge and social practice is an important medium through which agricultural power can be studied".

The discursive practices surrounding the agriculture-nature / agri-environment / agrifood interface have been the subject of research attention (Lowe and Ward, 1997; Clark et al., 1997; Morris and Young, 2000). Methodologically, interview transcripts and printed media are most commonly used as textual sources. For example, Morris and Young's (2000) analysis of discourses of food quality and quality assurance schemes in the British agricultural press has revealed how quality is contested and a focus of resistance and disagreement amongst different agro-food system actors. Other documentary sources have also been the subject of 'discourse analysis'. European agricultural policy documents (together with the transcripts of interviews with policy makers) provided the focus of Clark et al.'s (1997) 'discourse approach' to the analysis of the 'greening' of European agricultural policy. They make a strong case for the examination of discourse in this context, observing "agricultural policy researchers have been overly preoccupied with theorising the role of interests, at the expense of ideas, in their analyses of national and supranational policy development" (Clark et al., 1997, p.1870, emphasis added). By adopting a discourse approach, they are able to demonstrate how the culture of European policy making has sustained a particular 
vision of agricultural and agri-environment policy in which agricultural land occupancy and the small scale, family farm are central concepts.

The relative merits of these discourse centred accounts of rural and agricultural change are summed up by Buttel (1998, p.1152) who suggests that they have:

"led to some notable advances, particularly by documenting the fact that discursive practices are important guides to social action, and pervasive and potentially efficacious resources in political struggles".

However, he goes on to identify two reasons why caution should be exercised in the analysis of "the processes of rural and agricultural change that privilege the social origins and patterns of articulation of discourses" (Buttel, 1998, p.1152). The first is that although the analysis of discourse potentially side-steps the problem of structural determinism, this is only achieved by putting in its place "an equally one-sided voluntarism". The situating of discourse-based explanations of agricultural change within the theoretical perspective of political economy, as advocated by Clark et al. (1997) may be one way of addressing this difficulty, permitting a more balanced view of the interplay between cultural practices and the structural constraints which are configured by, and reconfigure, them. Nevertheless, there is resonance here with wider debate in rural geography, for whilst an intermediate position may be useful, it remains inadequate to resolve the issue of culture as an 'ingredient' of study or as a focus of analysis (Philo, 1992; Murdoch and Pratt, 1993). The second reason concerns a danger that the study of discursive practices becomes "a de facto form of structural determinism if it is presumed that the course of social action or fate of discursive exercises or struggles is essentially a reflection of the power of the groups that advance these narratives" (Buttel, 1998, p.1152). Examination of the complex ways in 
which discourses, that are seen as structuring the lives of particular agricultural groups, are negotiated by these groups offers scope to guard against this weakness (Liepins, 1998). A cultural emphasis is useful here because culture can act as a facilitator or resistance to the discourses of power, refracting them and necessitating their continual reciprocal modification.

\subsection{Nature-society relations}

"It is important that ... work [on the relationship between nature and society] is noted in the context of the 'cultural turn' in rural studies" (Little, 1999, p.440). The intersection between cultures of nature and rural studies is revealing new and vibrant research directions, including those on 'geographies of animals and flora; studies of non-human agencies relating to theorizations of hybridity and actor-networks, and the focus on embodiment, gender and spirituality' (Cloke, 1997, p.371). As Cloke (1997) observes, 'nature' can no longer be disregarded, treated as a backdrop or viewed in isolation as a socio-cultural construction. The fact that agricultural production and the wider food chain are notable for a preponderance of animals, actors and advertising using the body (human or animal) should place agricultural geographers at the forefront of this work. As agricultural activity is so bound up with 'nature', it would be easy to reduce a review of research on nature-society relationships to the confines of agricultural policy debates. Indeed, in recent years, this has centred firmly upon the relationship between agriculture and the environment, and particularly the ways in which farmers interpret environment. Many of these studies might be broadly characterised as 'social constructivist' in that they reject realist perspectives on the environment. Instead, emphasis is on the inseparability of nature and society and the need to explore cultures of nature(s); the spatially and temporally contingent ways in 
which people come to understand and apply meaning to nature and the environment (MacNaughton and Urry, 1998; van Koppen, 2000). This type of agri-cultural research has begun to uncover the different constructions of the environment amongst farmers, and particularly the contrasting meanings and understandings of nature, and the appropriate management of nature, between farmers and so-called environmental 'experts', including those from conservation organisations and policy-makers (Carr and Tait, 1991; McEachern, 1992; Walsh, 1997; McHenry, 1998; Holloway, 1999). As Burgess et al. (2000, p.120) summarise, this "social and cultural research has shown that farmers and conservationists may view the same landscapes or species, but see them quite differently". The context of these studies has been specific agrienvironment schemes, localities of high nature value and environmental issues (habitat management, climate change ${ }^{10}$ ). McEachern's (1992, p.168) ethnographic study of the Yorkshire Dales National Park, for example, detailed how the Park officers 'often perceived as 'dreadful' and 'ugly' the parts of the landscape which the farmers most admired: the pastures and fields extending far up the fellsides, destroying diversity and wildlife habitats". In the exploration of these contrasting understandings of nature and the environment, such studies have also been concerned with the (re)production of farmer and farming community identities ${ }^{11}$.

However, whilst not denying the value of such work to improving short-term 'on the ground' environmental conditions, thinking associated with it remains policy-led and bounded by conventional understanding. Far less common are views of agriculture

\footnotetext{
${ }^{10}$ Although not an agricultural study, the contribution of Jackie Burgess's work on the study of environmental meanings must be acknowledged (Burgess, 1990; Harrison and Burgess, 1994)

${ }^{11}$ The study of the identities of various rural groups represents a significant element of the cultural turn within non-agricultural rural studies (Cloke and Little, 1997; Little, 1999).
} 
which consider the policy approach to nature in broader terms, be it as part of a 'standard view' of post-event environmental remedy, ecological modernisation or the delivery of environmental justice (Harvey, 1996). Only relatively recently have researchers begun to apply such thinking to agricultural change (Evans et al., 2002). More robust has been the progress made in farm-focused research concerning knowledge(s) about nature and the environment. The conflicts and negotiations that take place at the interface between local / lay and scientific / expert, knowledge forms and 'knowledge-cultures' have increasingly occupied agri-cultural researchers (Kloppenburg, 1991, Clark and Murdoch, 1997; Burgess et al., 2000). Greater diversity is evident here than in the attitudinal and agri-environmental scheme focus of work on constructions of nature. Hence, research has been conducted on environmental risks (Wynne, 1996; Holloway, 1999), organic agriculture (Morgan and Murdoch, 2000) and precision farming technology (Gerber et al., 1998; Morris and Winter, 1999; Tsouvalis et al., 2000). One theme recurrent in all specific topic areas is how the locally specific knowledge of farmers, which is created in large part through the experience of working closely with the land, can be contrasted with the scientific knowledge of agricultural and environmental experts (Harrison et al., 1998). As Wilson (1997, p.307) asserts, in the context of assessment of the environmental impact of the Environmentally Sensitive Area Scheme:

"...farmers usually know their land better than other actors, and are, therefore, in a good position to evaluate subtle changes over large areas on their farms that are intractable even with the most sophisticated...permanent monitoring plots... Yet, positivist quantitative approaches are often seen as providing more 'solid' information than the more 'intangible' knowledge that local actors may have about the ecology of their area". 
Moreover, work of this kind has clear, practical implications, as indicated by Burgess et al. (2000, p.131):

"Nature in general, and wetlands in particular, might be better aided if scientific conservation were to concede more ground to local knowledge and local specificity. And if farmers were to give more recognition to the invisible wildlife that shares their space, but is not part and parcel of their everyday lives".

All of this research has provided fresh, and increasingly sophisticated, insights into the relationships between the natural and social worlds in the context of agriculture. These are valuable because they have the potential to inform new thinking and practice which can contribute towards the general societal goal of developing more sustainable agricultural systems.

The observation that particular knowledge forms (notably, scientific) are privileged over others (local knowledges) within the context, for example, of the conventional agricultural industry (Holloway, 1999; Morgan and Murdoch, 2000) or policy debates about agri-environment schemes (Burgess et al., 2000), has lead some researchers to adopt actor network theory (ANT). This enables the different understandings and knowledges of agriculture that are held by different actors, be they farmers, local residents, environmentalists or policy-makers to be treated symmetrically, or on an equal basis, with no a priori distinctions between different categories (see Clark and Murdoch, 1997; Lowe and Ward, 1997; Burgess et al., 2000). An important development is that ANT has been advanced as a means of overcoming the anthropocentric tendencies in studies of nature-society relations in social science generally and in the specific context of agriculture (Evans and Yarwood, 2000). This 
has begun to assist agricultural geographers in the process of, in Wolch and Emel's (1998) words, 'bringing the animals back in' to analysis ${ }^{12}$. Interestingly, despite the alliance of agriculture with animals, there remains a greater research emphasis in geography on 'wild' and 'domestic' animal-human relations than on farm livestock (see Philo and Wilbert, 2000). Nevertheless, new agricultural geographies of farm animals have begun to appreciate the distinctiveness of different breeds of farm livestock in the cultural landscape (Evans and Yarwood, 1995; Yarwood and Evans, 1998), and also to challenge the "inevitable and universal farmer-conservationist orthodoxy" in an examination of the Rare Breeds Survival Trust (Evans and Yarwood, 2000). Some considerable effort has recently been accorded to discussing the relative merits of ANT (e.g. Murdoch, 1997; Goodman 1999; Marsden, 2000) which represents a distinct, but still largely embryonic, strand within 'agri-cultural' research. Similarly, the ethics of human-animal relations are only now starting to be explored. In a study of small-scale hobby farmers, Holloway (2000) reveals how socially and agriculturally constructed views of animals as 'pets' or food (livestock or 'protein') become blurred in an ethically ambiguous relationship.

Contestations over the meaning of 'natural' have occurred at other points within the agri-food system beyond the farm gate, attracting research attention from agricultural geographers. Tentative steps are being taken to account for the way in which technology (particularly genetic engineering) is replacing any distinction between nature and culture through the creation of hybrid or cyborg objects (Murdoch, 1997). This has led to contestation of meanings of 'natural' within agro-food systems, indicating the ways in which body spaces of animals may become reconfigured

\footnotetext{
${ }^{12}$ Animals have always been a feature within agricultural geography, as the tradition of mapping their incidence testifies (see
} 
(Whatmore, 2000). There is also a struggle for control of the concept of 'natural' among food system actors, which, it is posited, is becoming increasingly pronounced in an age of consumer concerns about the standard or 'quality' of food from industrial systems. Such issues are developed by Murdoch et al. (2000) in an exploration of the relationships between quality, nature and the embeddedness of Welsh food supply chains. Food consumption has an important relationship with human embodiment, another emergent area of interest within rural studies (Bell and Valentine, 1997; Whatmore, 1997; Little, 1999; Atkins and Bowler, 2001, pp.304-306; see also the section below on enculturing the agri-food economy).

\subsection{Heterogeneous Agri-cultures}

As Morris and Evans (1999, p.354) have argued, 'Greater attention should be paid to cultural constructions of different groups within the farming 'community', which is all too frequently assumed by investigations of non-farming people in rural locales to be homogeneous' (see also Vanclay et al. (1998) who have reached the same conclusion). In some ways, the treatment of farming as a homogenic unit has become more common as the focus of rural based research has shifted away from agricultural production. From its former central position, agriculture is often relegated to the position of a single cultural enclave in which farmers are just one of many groups or actors. In his elaboration of the ways of understanding culture in economic geography, Crang (1997) identifies that culture has been used both as a 'generic facet of human life' emphasising processes of meaning creation and as a 'differential quality'. It is this latter understanding of culture which can help to delineate research into 'agri-cultures'. Crang suggests that understood in this way, culture marks out and 
helps to constitute distinctive social groups, each with their own meaning and value systems. However, studies which take as their starting point the cultures of particular groups within, or associated with, farming have not received the attention that might be expected. Vanclay et al. (1998) have drawn attention to the notion of farming subcultures which seems to offer exciting possibilities at first glance. Unfortunately, this is very partially developed in its own right and is instead presented as a critique of van der Ploeg's (1994) work on farming styles. Further, it focuses upon 'the farmer' as a principal operator and the ways that person approaches business management and farm work. Groups within agriculture such as non-family hired workers, contractors spraying chemicals, shepherds, rare breed keepers and independent women farmers seem to have greater surface resonance with the idea of subcultures, yet they remain sorely neglected.

A tradition exists within agricultural geography which utilises broad place distinctions founded in physical space ${ }^{13}$ as a way to add dimensions of specificity or comparison to empirical research. Three are common, namely the 'uplands' (sometimes 'marginal fringe'), lowlands (occasionally 'prosperous lowlands') and 'urban fringe'. Work on agri-cultures has frequently taken as a starting point a distinctive farming locality situated clearly within this broad framework and sought to map out the farming culture(s) therein. Studies of cultures within lowlands, such as those associated with wetlands or horticultural production for example, tend to be limited by their residual nature in the face of potent agrarian change. Hence, it is the uplands in particular that feature prominently, as it is here that cultural resistance to homogenising processes of

\footnotetext{
${ }^{13}$ As opposed to developmental space in which preserved, contested, paternalistic and clientelist types of countryside have been defined - see Murdoch and Marsden (1994).
} 
change within the agricultural sector has been strongest. The work of McEachern (1992) in the Yorkshire Dales; Hermann and Shucksmith (1994) in the Cairngorms; Gray $(1996 ; 1998)$ in the Scottish borders and McHenry (1998) also in Southern Scotland are all good examples. Indeed, Gray (1996) develops the idea that hill localities have their cultural differences reified by the Common Agricultural Policy (CAP).

For the most part methodologically, such work entails the use of ethnographic techniques such as participant and non-participant observation, usually associated with the discipline of anthropology, arguably the home of the study of culture(s). In some senses, new agri-cultural studies are redolent of the social anthropological rural community studies genre. This contains a wealth of descriptive material on farming by default due to the former importance of agriculture in rural economy and society generally. Similar concerns were addressed, such as the relationship between family and land (Williams, 1956), the valuation of farm work (Littlejohn, 1963) and farming customs (Rees, 1950). Later, behavioural work in agricultural geography became strong and also sought to engage with individuals, albeit through standardised methodologies devised with the purpose of composing decision-making models. However, it is true to say that most agricultural geographers have arrived at farms with pre-structured or semi-structured questionnaires, whether or not the intention is to tape record interviews and transcribe at a later date. In opting for an ethnographic methodology, Gray (1996) criticises this approach for assuming precise knowledge is held by the researcher about what is important to analyse. Paradigms may have shifted over time, but the basic approach to methodology in agricultural geography research has remained remarkably constant. Few researchers visit the same farm on multiple 
occasions and interaction with all members of a farming business or farm family household is seldom sought. Most work is confined to snapshot opinions of the 'principal' (usually male) operator of the farm business, with occasional longitudinal comparisons of these views made (as by Walford and Burton (2001), for example). Overall, this has led Hughes et al. (2000, p.10-11) to observe that "ethnographic methodologies have not been adopted ... widely in ... areas of rural research such as in agricultural geography".

Without dismissing earlier traditions, the recent work on 'agri-cultures' adopts a distinctive approach that goes beyond the sometimes rather descriptive and insular accounts of community studies and mechanistic methodologies of behaviouralism. In a rare early example, Pile (1991) conducted monthly 'interviews' for one year with six farmers to gain an understanding of how they viewed the power of people and institutions within their political worlds. The focus was upon farmers' use of language to assess their interpretation of the importance of structures and agents affecting their farming lives. Interestingly, this work was conducted from a generally structuralist theoretical perspective and also included the 'insurance' of a semistructured questionnaire conducted with farmers drawn from 44 parishes in the study area. More recently, Gray (1996) set out to challenge and critique political economic analyses of agricultural change which treat external forces on family farm businesses as unmediated. Drawing on a number of social theorists, including Bourdieu and Heidegger, he seeks to develop an 'interpositional' account of "how hill sheep farmers create a distinctive form of production, social world and identity at the same time as they are drawn into and forge external relations with the European Community [sic], whose policies determine the viability of their farms"(p.28). Understanding the 
'cultural mediation' of technological, economic and political processes by the farming community within Teviothead lie at the heart of this 'agri-culture'. A link with the (re)consideration of animals, noted in the last section, also emerges. Sheep are identified as an economic asset, yet farmers view them as an embodiment of "the natural qualities of the ground on which they graze', as well as 'the skills of the farmer' and shepherd(s) and including that of their forebears (Gray, 1996, p.43). A key to the cultural value of upland sheep is that they 'heft', or learn (from their mothers) to remain associated with specific areas of grazing land, being utilised by farmers as breeding units. This is based on inheritance of specific characteristics within sheep across the generations, just as generations of humans attempt to retain a distinctive family identity on the farm itself. The consideration of such issues is a long way from simply counting sheep as economic units of production. Away from specific localities, the cultures shared by agricultural groups who are not necessarily geographically proximate have also been studied to reveal cultural effects. Notable here is the work by Lowe et al. (1997) and Seymour and Revill (2000) on agricultural pollution advisors and inspectors and Holloway's (2000) study of smallholders. All of these studies have provided rich descriptions of the form and operation of distinctive agri-cultures, and "new understandings of farmer identities and farming lifeworlds" (Holloway, 2000, p.308).

\subsection{Enculturing the agri-food economy}

The final type of work discussed here as representing an agri-cultural turn is one that is arguably the least concerned with 'the farm' at the point of production. It encompasses the import (both consciously and not) of cultural considerations into the analysis of the wider agri-food economy. The introduction of ideas about political 
economy into agricultural geography was instrumental in moving researchers' attention beyond the farm gate and down the food chain towards an interest in the consumption of food. Hence, there is a distinct body of work focusing on food issues which can be regarded as having its roots in agricultural geography and demanding brief attention in this paper. In a review of the notion of agribusiness, Wallace (1985) remarked how little agricultural (and industrial) geographers had contributed to an understanding of the dynamics of the agri-food system up to that point in time. Bowler and Ilbery (1987) identified the food chain as a concept to integrate research into outward links from the farm at the point of production, whereas Atkins (1988) more radically called for a replacement of agricultural geography with a 'geography of food'. Such remarks were important catalysts in the development of political economy perspectives to consider the notion of food regimes, including the application of insights from regulation theory (McMichael, 1994), globalisation of food systems (Le Heron, 1993) and influence of transnational corporations in food manufacturing and processing (Goodman and Watts, 1997).

Evidently, the application of a political economy perspective has meant that much progress has been made, but it has been unable to expose the diversity, real or artificially created, that exists within food systems. Hence, interest has grown in food networks (Marsden and Arce, 1995), including the application of actor network theory to their analysis (Whatmore and Thorne, 1997) and local (endogenous) influences in the development of food products (van de Ploeg and Long, 1994). This connects into a wider set of debates within human geography about the relationship between the economic and the cultural (Thrift and Olds, 1996; Lee and Wills, 1998; Ray and Sayer, 1999) in which culture is increasingly key to economic geography's research 
agendas (Crang, 1997). Hence, research into agri-food topics has been significantly reinvigorated by the turn to culture.

One exemplar of the 'enculturation' of research on the agri-food economy is the investigation of the social construction of 'quality' food. The political economy perspective was able to offer incisive analysis of the trend towards global sameness and the production of more profitable foods by large companies within a mass food production system (Le Heron, 1993). However, it was less able to cope with the emerging contradictory trend within capitalism towards consumer preferences for perceived diversity, taste, safeness and traceability of food based on localness as a metaphor for 'quality'. Indeed, different meanings become attached to quality by different actors within agro-food networks as they seek to gain economic advantage and protect their interests. For example, Ilbery and Kneafsey (2000, p.218) highlight how "regulatory institutions may be concerned with the so-called objective indicators of quality, such as the application of hygiene requirements in the case of food products. The very objectivity of these indicators is in itself socially constructed and will vary according to political and economic pressures, scientific understandings and cultural contexts. Consumers may be interested in what have been traditionally described as subjective indicators of quality such as experiential phenomena which lie in the eye of the beholder, while producers may emphasise raw materials and methods of production" (see also Morris and Young, 2000; Murdoch et al., 2000; and Parrott et al., 2002). The study of the meanings and ideologies attached to particular food production-consumption spaces, such as farmers' markets is also indicative of an increased sensitivity to the role of cultural processes in the current reshaping of British foodscapes (Holloway and Kneafsey, 2000). 
The cultural embeddedness of economic processes, which Barnett (1998a) identifies as one manifestation of human geography's cultural turn, has also begun to receive attention within agri-food research. It this context, embeddedness recognises that the social and the cultural cannot be disassociated from the economic aspects of food production and consumption. As Ilbery and Kneafsey (2000, p.218) explain:

"The current combination of demands and regulations [on the agro-food sector] could offer potential for a 'cultural relocalisation' of food production in which locally produced SFPs [speciality food products] with designations of authenticity of geographical origin are transferred to regional and national markets...This does not entail a physical relocation of production but rather a conscious 'fixing' of local SFPs or regional cuisines to territory".

It is likely that the issue of embeddedness within the agri-food sector will attract further research attention, particularly given current public and political concerns about food production, together with the potential of re-embedded food chains to provide rural development and environmental protection opportunities (Murdoch et al., 2000;). For example, in 2000, the Countryside Agency ${ }^{14}$ launched its 'Eat the View' campaign, which is based on the belief that "some products, because of the way they are produced, their area of origin, or other qualities, can help maintain the environmental quality and diversity of the countryside while at the same time bringing benefits to the rural economy and local communities" (Countryside Agency, 2000).

\footnotetext{
${ }^{14}$ The Countryside Agency defines itself as the statutory body in England working to: conserve and enhance the countryside; promote social equity and economic opportunity for the people who live there; and help everyone, wherever they live, to enjoy this national asset.
} 
An encultured agricultural geography, reinforced by the changing research agenda in economic geography, has led researchers to engage more directly with the geography of food. Although extending beyond the farm, the studies referred to above are, for the most part, concerned with a production-consumption link. Often, their purpose has been to gain a better understanding of rural development processes or drivers of agricultural change. However the geography of food has simultaneously become characterised by a research dimension that makes no explicit link with production, making it distinct from the concerns of agricultural geography ${ }^{15}$. Hence, there is a food consumption perspective which, perhaps confusingly for a discussion about the application of culture in agricultural geography, has adopted cultural analysis in a highly explicit way (e.g. Bell and Valentine, 1998). Thus, the topic of food has provided a useful vehicle to demonstrate the relevance of the application of cultural ideas in geography, but in a context removed from production. The work by Cook, Crang and Thorpe is exemplary in this regard (e.g. Cook, 1994; Cook and Crang, 1996; Cook et al., 1998; Cook et al., 2000). A key focus of their research is the various meanings ascribed to food as it moves through the agro-food system and the 'work' (or material consequences) of these meanings. For example, in his analysis of the production and consumption of exotic fruit, Cook $(1994,232)$ suggests that, "the meanings that companies attempt to ascribe to these fruits play a crucial role in the articulation of commodity systems.....just because they are produced and packed in one place and shipped, ripened and delivered fresh to a store in another, it does not necessarily follow that anyone will buy them. In short, there is a symbiotic relationship between the 'material' production of a fruit or vegetable and the

\footnotetext{
15 In the discipline of rural sociology, Goodman and Depuis (2002, p.6 and p.9) have similarly identified a 'glaring subdisciplinary disjuncture' between, in this case, rural 'production' sociology and the sociology of food.
} 
'symbolic' production of its meanings". The meanings and understandings of food that are held by consumers are further explored by Cook et al. (1998) who assert that in both academic and agro-food industry accounts, the consumer tends either to be constructed as knowledgeable (and therefore powerful) or ignorant (and, by implication, manipulated) of the origins of their food. Moving away from this 'blunt dichotomy' Cook et al. (1998) begin to work with more subtle and sophisticated understandings of consumers' relations to systems of provision, identifying a 'structural ambivalence' within consumers' relationship with the rest of the food system. This involves both an impulse to forget and a need to know about the origins of the food they consume, suggesting a two-way relationship between producers and consumers in which consumer knowledges of the origins of food are both structured by and help to create relations with food provision.

\section{Future (agri)culture?}

Collectively, the work outlined above suggests that there is more than sufficient evidence to support the claim that agricultural research has experienced a cultural turn during the 1990s. However, as is the case elsewhere within the social sciences, the coherence of this agri-cultural turn, and the extent to which it has been a selfconscious development, is debatable. Furthermore, and unlike that in human geography as a whole, the agri-cultural turn can hardly be described as being too successful and too hegemonic (Philo, 2000). The fragmentary nature of the evidence and diversity of origin of the studies briefly referred to in this paper hardly lend much weight in a geographical context to Buttel's (2001) assertion that cultural turn studies in the sociology of agriculture have rivalled those of agrarian political economy. 
The preceding sections have revealed some of the limits of agri-cultural turn studies, but new and exciting research directions have already emerged implicitly from the review process. The objective of this concluding section is to make more explicit the value of culturally informed work and to sketch the future relevance of further enculturing geographical studies of agriculture. This seems all the more pressing in the light of Barnett's (1998b) observation that cultural analyses have been haunted by doubts about political relevance, and in the context of rural studies, Little's (1999, p.437) assertion that "the application of the cultural turn has, at times, been simplistic and uncritical". A key concern is:

" the theoretical and political purpose (or end point) of such research ... It has been suggested that too strong an emphasis on the cultural construction of rural society and marginalisation will encourage description and detract from an examination of the underlying causes and processes of disadvantage" (Little, 1999, p.439).

Such concerns have been expressed within agricultural geography, where the cultural turn may be viewed as a luxury or distant from the research project of generating data to inform policy that addresses the plight of farming lives and businesses (Battersby, 2000). However, this impression need not pervade given the centrality of culture to the very meaning of agriculture.

A review and assessment of an agri-cultural turn demonstrates the need to continue to make space for the cultural within agricultural geography research. It is apparent that a new cultural geography of agriculture can contribute positively to the evolution of a more robust theoretical, methodological and empirical foundation for the sub-field. By way of conclusion, each can be briefly illustrated. Culturally informed analyses of agriculture offer alternative theoretical insights to those from the rather deterministic 
and structural analyses of political economy, or provide a more satisfying 'balance' demanded from a modified political economy. There is an acknowledged tension between cultural approaches and political economy (see Cloke, 1994; Little, 1999), but the adoption of one does not necessarily entail the rejection of the other. In this sense, Cloke's (1997, p.372) conclusion about the cultural turn in rural studies has much to recommend it. He asserts that there is a need:

"to retain....important insights from political economy approaches and to place these alongside some of the exciting ways of seeing rurality and ways of doing rural studies which draw on aspects of the cultural turn" (emphasis added).

This resonates with Lowe and Ward's (1997, p.270) suggestion that "the search for new, all encompassing paradigms is an insufficiently modest objective. Better to revel in theoretical and methodological diversity and be promiscuous in our interests and approaches". In a similar vein, the conclusion drawn by Philo (2000, p.44) about human geography's cultural turn can also be applied to research into agriculture: "enquiry should embrace the material and the social (thereby resisting any dogmatic dematerialising or desocialising...) but also continue to draw inspiration from the whole sweep of the cultural turn". The juxtapositioning of cultural with other approaches is possible and rewarding, as Yarwood and Evans (2000) demonstrate in their examination of the geography farm livestock.

Methodologically, greater complementarity between cultural and other established perspectives means that agricultural geographers will need to engage with more innovative research methods than those based on questionnaires. Some of the agricultural work referred to above has deliberately set out to utilise methodologies which are sensitive to the interplay between textual representation and structural contexts, as 
Clark et al. (1997) have attempted with their work on EU agricultural policy. Nevertheless, here is room for a far greater diversity of ethnographies, focus group work, and participation activities ${ }^{16}$ to name but a few which can be used with the full range of individuals (or subcultures) associated with farming activities.

Agri-cultural research has a particular empirical relevance through an exploration of the relationship between agri-cultural perspectives and policy. Little (1999) has also suggested that making links between cultural approaches to rural marginalisation with political practice and policy is one means of negotiating some of the difficulties with (uncritical) cultural rural studies. Although 'policy orientation' was identified earlier as one explanation for the relative paucity of culturally informed agricultural research, more often than not agri-cultural work has been situated quite deliberately within a distinctly scientific policy context (as with most of the agri-environmental work outlined above). Moreover, given the current re-directions in agricultural and rural policy, there is considerable value in promoting greater levels of cultural sensitivity among researchers and policy-makers alike. Four features of rural policy can be illustrated where further contributions from culturally informed agricultural research would be telling.

The first relates to policy developments concerned with the environment and nature, and suggests an extension of the agri-cultural work on 'nature-society relations'. Although agri-environment schemes, such as the Countryside Stewardship Scheme and Environmentally Sensitive Areas, purport to be sensitive to some of the (selected)

\footnotetext{
${ }^{16}$ Burgess (2000) provides an excellent example of how a more participatory approach to research may be deployed within the context of environmental policy and decision making that is informed by the cultural turn. Indeed Burgess and colleagues have a clear project to 'make cultural geography work'.
} 
idiosyncrasies and traditions of local farming practice, policy evaluation work has taken insufficient account of this dimension. This is aside from questions about the extent to which such policies have been designed and implemented along culturally sensitive lines, at least in a British context). Similarly, the relatively new concept of biodiversity action plans (BAPs) includes biodiversity targets that are both national in scope and also reflect the values local people, local conditions and local distinctiveness. The challenges involved in incorporating 'local natures' (including farming's natures) within BAPs have only just begun to be addressed (see Harrison et $a l .$, 1998). Thus, further investigations of the relationship between local agricultural knowledges and understandings of nature / environment, local agricultural practices and the development of nature conservation and agri-environment schemes, plans and policies are essential.

Secondly, as rural and agricultural policy becomes increasingly restructured into regional subsidiarity ${ }^{17}$, it seems wholly appropriate to advocate further research which maps out the regional and sub-regional differences in agri-cultures, as an important means of informing decisions about the future shape and form of regionally specific policy.

Thirdly, despite widespread neglect, human-livestock relations are not only actively affected by, but are active in affecting, policy towards agriculture, thus impacting directly upon policy goals. Discussions over the policy approach to the future of agriculture, such of that of the Policy Commission on the Future of Farming and Food

\footnotetext{
${ }^{17}$ Notably, the England Rural Development Plan (the means of implementing the Rural Development Regulation) comprises a national framework document with 9 regional chapters based on Government Office Regions. Each region has a Regional Planning Group that is responsible for sensitising the measures available under the RDR to local needs and conditions.
} 
(2002) will remain partial and unsatisfactory in the absence of research that addresses directly human-livestock relations. In fact, human-animal interactions lie at the centre of the public representation of farming and to the challenges voiced about the intensive ways in which agriculture is practiced, manifest most commonly as concerns over animal welfare, food safety and environmental quality. An understanding of such relations using cultural insights will lead to a more complete and critical understanding of agricultural policy frameworks than achieved hitherto.

The fourth feature of policy that validates further research on 'enculturing the agrifood economy' is concerned with diversifying and strengthening the rural economy and specifically with adding value to food and other rural products. The Countryside Agency's 'Eat the View' campaign is one illustration of this policy concern. Cutting across these programmes and policy debates is the notion of embeddedness already discussed. As indicated in the review, agri-cultural work has only recently begun to explore the potential of re-embedding food chains in providing rural development and environmental protection opportunities. These issues have become central to the future of British farming, forming the basis of the Policy Commission on the Future of Farming and Food (2002) recommendations that government has become committed to implement.

Agri-cultural research, therefore, has much to contribute to current farming and rural policy debates. As this paper has demonstrated, the growing body of work suggests that agricultural geographers in the UK have engaged with the cultural turn, but that much remains to be done to improve our understanding of the complexities of the agrarian sector. The possibilities are wide-ranging, but of immediate importance are 
considerations of the cultural construction of different groups within the farming community (drawing on work on the rural 'other') and 'political ethnographies' of those organisations responsible for the formulation of food and agricultural policy (Winter and Potter, 1999). A move beyond the 'conventional' view of farming is also within the grasp of agricultural geographers, including evaluations of alternative landholding structures, such as citizen contracted countryside stakeholders (Rose, 2002). An agri-cultural turn in this sense, then, implies a turn towards and, embracing of, contemporary policy and public concerns about the agricultural sector. However, this is not to advocate an agri-cultural research agenda in geography designed exclusively for policy audiences. Agri-cultural research possibilities can, and should, be equally associated with academic questions about the future of agriculture and the food system.

\section{References}

Arensberg, C., Kimball, S., 1940. Family and Community in Ireland. Harvard University Press, Harvard.

Atkins, P., 1988. Redefining agricultural geography as the geography of food. Area 20, 281-283.

Atkins, P. and Bowler, I., 2001. Food in Society. Arnold, London.

Barnett, C., 1998a. The cultural worm turns: fashion or progress in human geography? Antipode 30, 379-94.

Barnett, C., 1998b. Cultural twists and turns. Environment and Planning D: Society and Space 16, 631-4.

Battersby, S., 2000. Personal communication. 
Bell, D. and Valentine, G., 1997. Consuming Geographies: we are where we eat. Routledge, London.

Bell, M., 1994. Childerley: Nature and Morality in a Country Village. University of Chicago Press, Chicago.

Bouquet, M., 1985. Family Servants and Visitors: the Farm Household in Nineteenth and Twentieth Century Devon. Geobooks, Norwich.

Bowler, I. and Ilbery, B., 1987. Redefining agricultural geography. Area 19, 327-332.

Burgess, J., 1990. The production and consumption of environmental meanings in the mass media: a research agenda for the 1990s. Transactions of the Institute of British Geographers 15, 139-161.

Burgess, J., Clark, J., Harrison, C., 2000. Knowledges in action: an actor network analysis of a wetland agri-environment scheme. Ecological Economics 35, 119-132.

Buttel, F., 1998. Nature's place in the technological transformation of agriculture: some reflections on the recombinant BST controversy in the USA. Environment and Planning A 30, 1151-1163.

Buttel, F., 2001. Some reflections on late twentieth century agrarian political economy. Sociologia Ruralis 41, 165-179.

Carr, S., Tait, J. (1991) Farmers' and conservationists' attitudes. Journal of Environmental Management 32, 281-294.

Clark, J., Jones, A., Potter, C., Lobley, M., 1997. Conceptualising the evolution of the European Union's agri-environment policy: a discourse approach. Environment and Planning A 29, 1869-1885. 
Clark, J., Murdoch, J., 1997. Local knowledge and the precarious extension of scientific networks: a reflection on three case studies. Sociologia Ruralis 37, $38-60$.

Cloke, P., 1994. (En)culturing political economy: a life in the day of a 'rural geographer'. In Cloke, P., Doel, M., Matless, D., Phillips, M., Thrift, N. (Eds.), Writing the Rural: Five Cultural Geographies. Paul Chapman, London.

Cloke, P., 1997. Country backwater to virtual village? Rural studies and 'the cultural turn'. Journal of Rural Studies 13, 367-375.

Cloke, P. and Little, J. 1997. Contested Countryside Cultures: Otherness, Marginalisation and Rurality. Routledge, London.

Cook, I. 1994. New fruits and vanity: symbolic production in the global food economy. In Bonanno, A., Busch, L., Friedland, W., Gouveia, L. and Mingione, E. (Eds.), From Columbus to ConAgra: the Globalisation of Agriculture and Food. University Press of Kansas, Kansas.

Cook, I., Crang, P., 1996. The world on a plate: culinary culture, displacement and geographical knowledges. Journal of Material Culture 1, 131-153.

Cook, I., Crang, P., Thorpe, M., 1998. Biographies and geographies: consumer understandings of the origins of foods. British Food Journal 100, 162-167.

Cook, I., Crang, P., Thorpe, M., 2000. Regions to be cheerful: culinary authenticity and its geographies. In Cook, I., Crouch, D., Naylor, S., Ryan, J. (Eds.) Cultural Turns / Geographical Turns. Pearson Education, Harlow, pp.109-139.

Coppock, T., 1964. An Agricultural Atlas of England and Wales. Faber and Faber, London.

Countryside Agency, 2000. Eat the View. Countryside Agency, Cheltenham. 
Crang, P., 1997. Cultural turns and the (re)constitution of economic geography. In Lee, R., Wills, J. (Eds.) Geographies of Economies. Arnold, London.

Eagleton, T. 2000. The Idea of Culture. Blackwell, Oxford.

Emmett, I., 1964. A North Wales Village: a Social Anthropological Study. Routledge and Paul Kegan, London.

Evans, N., Morris, C. and Winter, M., 2002. Conceptualising agriculture: a critique of post-productivism as the new orthodoxy. Progress in Human Geography 26, 313-332.

Evans, N., Yarwood, R., 1995. Livestock and landscape. Landscape Research 20, 141 146.

Evans, N., Yarwood, R., 2000. The politicisation of livestock: rare breeds and countryside conservation. Sociologia Ruralis 40, 228-248.

Fish, R., Phillips, M., 1997. Explorations in media country: political economic moments in British rural television drama. Paper presented at the third BritishFrench Rural Geography Symposium, Nantes, September 1997.

Frankenberg, R., 1957. Village on the Border: a Social Study of Religion, Politics and Football in a North Wales Community. Cohen and West, London.

Gasson, R., 1973. Goals and values of farmers. Journal of Agricultural Economics 24, $521-537$.

Gerber, J., Holloway, L., Seymour, S., Steven, M., Watkins, C., 1998. New technologies and old knowledges: the impact of precision farming on the management of the English countryside. In: Croix, N. (Ed.), Environnement et Nature dans les Campagnes: Nouvelles Politiques, Nouvelles Pratiques. Presses Universitaires de Rennes, Rennes. 
Gillmor, D., 1986. Behavioural studies in agriculture: goals, values and enterprise choice. Irish Journal of Agricultural Economics and Rural Sociology 11, 1933.

Goodman, D., 1999. Agro-food studies in the 'age of ecology': nature, corporeality, biopolitics. Sociologia Ruralis 39, 17-38.

Goodman, D. and Depuis, M., 2002. Knowing food and growing food: beyond the production-consumption debate in the sociology of agriculture. Sociologia Ruralis 42, 5-22.

Goodman, D. and Watts, M. (Eds.), 1997. Globalizing Food: agrarian questions and global restructuring. Routledge, London.

Gray, J., 1996. Cultivating farm life on the Borders: Scottish hill sheep farms and the European Community. Sociologia Ruralis 36, 27-50.

Gray, J., 1998. Family farms in the Scottish Borders: a practical definition by hill sheep farmers. Journal of Rural Studies 14, 341-56.

Harrison, C. and Burgess, J., 1994. Social constructions of nature: a case study of conflicts over the development of Rainham Marshes SSSI. Transactions of the Institute of British Geographers 19, 291-310.

Harrison, C., Burgess, J., Clark, C., 1998. Discounted knowledges: farmers' and residents' understandings of nature conservation goals. Journal of Environmental Management 54, 305-320.

Harvey, D., 1996. Justice, Nature and the Geography of Difference. Blackwell, Oxford.

Harvey, D. 2000. Spaces of Hope. Edinburgh University Press, Edinburgh. 
Hermann, V., Shucksmith, M., 1994. Habitus and practise of farmers in Scotland and West Germany. In Corpus, A., Marr, J. (Eds.), Rural Realities, Trends and Choices. Proceedings of the $35^{\text {th }}$ EAAE seminar, Aberdeen, June.

Holloway, L., 1999. Understanding climate change and farming: scientific and farmers' constructions of 'global warming' in relation to agriculture. Environment and Planning A 31, 2017-2032.

Holloway, L., 2000. 'Hell on earth and paradise all at the same time': the production of small holding space in the British countryside. Area 32 (3), 307-316.

Holloway, L., Kneafsey, M., 2000. Reading the Space of the Farmers' Market: A Preliminary Investigation from the UK. Sociologia Ruralis 40 (3), 285-299.

Hughes, A., Morris, C., Seymour, S., 2000. Ethnography and Rural Research. Countryside and Community Press, Cheltenham.

Ilbery, B., 1985. Agricultural Geography: A Social and Economic Analysis. Oxford University Press, Oxford.

Ilbery, B. (Ed.), 1998. The Geography of Rural Change. Longman, London.

Ilbery, B., Kneafsey, M., 2000. Producer constructions of quality in regional specialty food production: a case study from south west England. Journal of Rural Studies 16, 217-230.

Jackson, P., Thrift, N., 1995. Geographies of consumption. In: Miller, D. (Ed.) Acknowledging Consumption: A Review of New Studies. Routledge, London, pp.204-237.

Jackson, P., Brooks, K., Stevenson, N., 1999. Making sense of men's lifestyle magazines. Environment and Planning D: Society and Space 17, 353-368.

Johnson, R., 1986. The story so far: and further transformations? In Punter, D. (Ed.)

Introduction to Contemporary Cultural Studies. Longman, London, pp.277-313. 
Kloppenburg, J., 1991. Social theory and the de/reconstruction of agricultural science: local knowledge for an alternative agriculture. Rural Sociology 56, 519-548.

Lee, R., Wills, J., (Eds.), 1997. Geographies of Economies. Arnold, London.

Le Heron, R., 1993. Globalized Agriculture. Pergamon Press, Oxford.

Liepins, R., 1996. Reading agricultural power: media as sites and processes in the construction of meaning. New Zealand Geographer 52, 3-10.

Liepins, R., 1998. 'Women of broad vision': nature and gender in the environmental activism of Australia's 'Women in Agriculture' movement. Environment and Planning A 30, 1179-1196.

Little, J., 1999. Otherness, representation and the cultural construction of rurality. Progress in Human Geography 23, 437-442.

Littlejohn, J., 1963. Westrigg: the Sociology of a Cheviot Parish. Routledge and Paul Kegan, London.

Lowe, P., Clark, J., Seymour, S., Ward, N., 1997. Moralizing the Environment: Countryside Change, Farming and Pollution. UCL Press, London.

Lowe, P., Ward, N., 1997. Field-level bureaucrats and the making of new moral discourses in agri-environmental controversies. In: Goodman, D., Watts, M. (Eds.) Globalising Food: Agrarian Questions and Global Restructuring. Routledge, London, pp.256-272.

MacNaughton, P., Urry, J., 1998. Contested Natures. Sage, London.

Marsden, T., 1988. Exploring political economy approaches in agriculture. Area 20, 315-322.

Marsden, T., 1998. Economic perspectives. In Ilbery, B. (Ed.) The Geography of Rural Change. Longman, London, pp.13-30. 
Marsden, T., 2000. Food matters and the matter of food: towards a new food governance? Sociologia Ruralis 40 (1) 20-29.

Marsden, T. and Arce, A., 1995. Constructing quality: emerging food networks in the rural transition. Environment and Planning A 27, 1261-1279.

Marsden, T., Munton, R., Ward, N., Whatmore, S., 1996. Agricultural geography and the political economy approach: a review. Economic Geography 72, 361-75.

Marsden, T., Murdoch, J., Lowe, P., Munton, R., Flynn, A., 1993. Constructing the Countryside. UCL Press, London.

Marsden, T., Whatmore, S., Munton, R. and Little, J., 1986. The restructuring process and economic centrality in capitalist agriculture. Journal of Rural Studies 2, 271-280.

McDowell, L., 1994. The transformation of cultural geography. In: Gregory, D., Martin, R., Smith, G. (Eds.) Human Geography: Society, Space and Social Science. Macmillan, London, pp.146-73.

McEachern, C., 1992. Farmers and conservation: conflict and accommodation in farming politics. Journal of Rural Studies 8, 159-171.

McHenry, H., 1998. Wild flowers in the wrong fields are weeds! Examining farmers' constructions of conservation. Environment and Planning A 30, 1039-1053.

McMichael, P. (Ed.), 1994. The Global Restructuring of Agro-food Systems. Cornell University Press, Ithaca, USA.

Meinhof, U., 1993. Discourse. In: Outwaite, W. and Bottomore, T. (Eds.) The Blackwell Dictionary of 20th Century Social Thought. Blackwell, Oxford, pp.161-162. 
Middleton, A., 1986. Making boundaries: men's space and women's space in a Yorkshire village. In: Bradley, T., Lowe, P., Wright, S. (Eds.) Deprivation and Welfare in Rural Areas. Geobooks, Norwich.

Milbourne, P., 2000. Exporting 'other' rurals: new audiences for qualitative research. In: Hughes, A., Morris, C., Seymour, S. (Eds.) Ethnography and Rural Research. Countryside and Community Press, Cheltenham, pp.136-157.

Morgan, K., Murdoch, J., 2000. Organic vs. conventional agriculture: knowledge, power and innovation in the food chain. Geoforum 31, 159-173.

Morris, C., Evans, N., 1999. Research on the geography of agricultural change: redundant or revitalised. Area 31, 349-358.

Morris, C., Evans, N., 2002. Cheesemakers are always women: gendered representations of farm life in the agricultural press. Gender, Place and Culture $8,375-390$.

Morris, C. and Winter, M., 1999. Integrated farming systems: the third way for European Agriculture? Land Use Policy 16, 193-205.

Morris, C., Young, C., 2000. 'Seed to shelf', 'teat to table', 'barley to beer' and 'womb to tomb': discourses of food quality and quality assurance schemes in the UK. Journal of Rural Studies 16, 103-115.

Murdoch, J., 1997. Inhuman-nonhuman-human: actor network theory and the prospects for a nondualistic and symmetrical perspective on nature and society. Environment and Planning D: Society and Space 15, 731-756.

Murdoch, J., Marsden, T., 1994. Reconstituting Rurality. UCL Press, London.

Murdoch, J., Marsden, T., Banks, J., 2000. Quality, nature and embeddedness, some theoretical considerations in the context of the food sector. Economic Geography 76, 107-125. 
Murdoch, J. and Pratt, A., 1993. Rural Studies: modernism, postmodernism and the 'post-rural'. Journal of Rural Studies 9, 411-427.

Newby, H., Bell, C., Saunders, P., Rose, D., 1977. Farmers' attitudes to conservation. Countryside Recreation Review 2, 23-30.

Parrott, N., Wilson, N., and Murdoch, J., 2002. Spatialising quality: regional protection and the alternative geography of food. European Journal of Urban and Regional Studies 9, 241-261.

Philo, C., 2000. More words, more worlds: reflections on the 'cultural turn' in human geography. In: Cook, I., Crouch, D., Naylor, S., Ryan, J. (Eds.) Cultural Turns / Geographical Turns. Pearson Education, Harlow, pp.26-53.

Phillips, M., 1998. Social perspectives. In Ilbery, B. (Ed.) The Geography of Rural Change. Longman, London, pp.31-54.

Phillips, M., Fish, R., Agg, J., 2001. Putting together ruralities: towards a symbolic analysis of rurality in the British mass media. Journal of Rural Studies, 17, $1-27$.

Philo, C., 1992. Neglected rural geographies: a review. Journal of Rural Studies 8, 193-207.

Philo, C., 2000. More words, more worlds: reflections on the 'cultural turn' and social geography'. In Cook, I., Crouch, D., Naylor, S. and Ryan, J. (Eds.) Cultural Turns / Geographical Turns. Longman, London, pp.26-53.

Philo, C. and Wilbert, C. (Eds.), 2000. Animal Spaces, Beastly Places. Routledge, London.

Pile, S., 1991. 'A load of bloody idiots': Somerset dairy farmers' view of their political world. Political Geography Quarterly 10, 405-421. 
Policy Commission on the Future of Farming and Food (2002) Farming and Food: a sustainable future (The Curry Report). Cabinet Office, London.

Ray, L., Sayer, A., 1999. Culture and Economy After the Cultural Turn. Sage, London.

Rapport, N., 1993. Diverse World-Views in an English Village. Edinburgh University Press, Edinburgh.

Rees, A., 1950. Life in the Welsh Countryside. University of Wales Press, Cardiff.

Rose, C., 2002. A missed connection in the cowshed. ECOS 23, 46-51.

Seymour, S., Revill, G., 2000. Telling stories: stories as textual strategy. In: Hughes, A., Morris, C., Seymour, S. (Eds.) Ethnography and Rural Research. Countryside and Community Press, Cheltenham, pp.136-157.

Short, J., 1991. Imagined Country. Routledge, London.

Strathern, M., 1982a. The place of kinship: kin, class and village status in Elmdon, Essex. In: Cohen, A. P. (Ed.) Belonging: Identity and Social Organisations in British Rural Cultures. Manchester University Press, Manchester.

Strathern, M., 1982b. The village as an idea: constructs of villageness in Elmdon, Essex. In: Cohen, A. P. (Ed.) Belonging: Identity and Social Organisations in British Rural Cultures. Manchester University Press, Manchester.

Thrift, N., Olds, K., 1996. Refiguring the economic in economic geography. Progress in Human Geography 20, 311-337. 
Tsouvalis, J., Seymour, S., Watkins, C., 2000. Exploring knowledge-cultures: precision farming, yield mapping, and the expert-farmer interface. Environment and Planning A, 32, 908-924.

Valentine, G., 2001. Whatever happened to the social? Reflections on the "cultural turn' in British human geography. Norsk Geografisk Tidsskrift 55, 166-172.

Vanclay, F., Mesiti, L. and Howden, P., 1998. Styles of farming and farming subcultures: appropriate concepts for Australian rural sociology? Rural Society $8,85-107$.

van der Ploeg, J., 1994. Styles of farming: an introductory note on concepts and methodology. In van der Ploeg, J. and Long, A. (Eds.) Born from within: practice and perspectives of endogenous rural development. Van Gorcum, Assen, Netherlands, pp7-30.

van der Ploeg, J. and Long, A. (Eds.), 1994. Born from within: practice and perspectives of endogenous rural development. Van Gorcum, Assen, Netherlands.

van Koppen, K. (2000) Resource, arcadia, lifeworld. Nature concepts in environmental sociology. Sociologia Ruralis 40, 300-318.

Walsh, M., 1997. The view from the farm: farmers and agri-environmental schemes in the Yorkshire Dales. The North West Geographer 1, 24-35.

Walter, G., Wilson, S., 1996. Silent partners: women in farm magazine success stories, 1934-1991. Rural Sociology 61, 227-248.

Walford, N. and Burton, R., 2000. The development of large-scale commercial farming in South-East England. School of Earth Sciences and Geography, Kingston University. 
Wallace, I. 1985. Towards a geography of agribusiness. Progress in Human Geography 9, 491-514.

Whatmore, S., 1993. Agricultural geography. Progress in Human Geography 17, 8491.

Whatmore, S., 1997. Dissecting the Autonomous Self: Hybrid Cartographies for a Relational Ethics. Environment and Planning D: Society and Space 15, 37-53.

Whatmore, S., 2000. Agricultural geography. Dictionary of Human Geography. Blackwell, Oxford.

Whatmore, S., Munton, R., Marsden, T. and Little, J., 1996. The trouble with subsumption and other rural tales: a response to critics. Scottish Geographical Magazine 112, 54-56.

Whatmore, S. and Thorne, L., 1997. Nourishing networks: alternative geographies of food. In Goodman, D. and Watts, M. (Eds.) Globalizing Food: agrarian questions and global restructuring. Routledge, London, pp.287-304.

Williams, W., 1956. The Sociology of an English Village: Gosforth. Routledge and Kegan Paul, London.

Williams, W., 1963. A West Country Village: Ashworthy. Routledge and Kegan Paul, London.

Wilson, G., 1997. Assessing the environmental impact of the ESA Scheme: a case for using farmers' environmental knowledge? Landscape Research 22, 303-326.

Winter, M., Potter, C., 1999. CAP Reform, liberalisation and farming futures, Paper presented to Rural Economy \& Society Study Group Conference, Royal Agricultural College, Cirencester.

Wolch, J. and Emel, J., 1995. Bringing the animals back in. Guest Editorial, Environmental and Planning D: Society and Space 13, 632-636. 
Woods, M., 1998. Mad cows and hounded deer: political representations of animals in the British Countryside. Environment and Planning A 30, 1219-1234.

Wynne, B., 1996. May the sheep safely graze? A reflexive view of the expert-lay knowledge divide. In: Lash, S., Szerszynski, B., Wynne, B. (Eds.) Risk, Environment and Modernity: Towards a New Ecology. Sage, London, pp.4483.

Yarwood, R., Evans, N., 1998. The changing geographies of domestic livestock animals. Society and Animals 6, 137-66.

Yarwood, R. and Evans, N., 2000. Taking stock of farm animals and rurality. In Philo, C. and Wilbert, C. (Eds.) Animal Spaces, Beastly Places. Routledge, London, pp.98-114.

Young, C., Morris, C., Andrews, C., 1995. Agriculture and the environment in the UK: towards an understanding of the role of 'farming culture'. Greener Management International 12, 63-80. 